\title{
A Pediatric Case of Cutaneous Larva Migrans in Turkey
}

\section{Pediatrik Kütanöz Larva Migrans Olgusu}

\author{
Şefika İlknur Kökçü Karadağ'(iD), Gonca Hancıoğlu'(iD), Fadıl Öztürk'(iD) \\ ${ }^{1}$ Department of Pediatrics, Ondokuz Mayis University School of Medicine, Samsun, Turkey
}

Cite this article as: Kökçü Karadağ şi, Hancıoğlu G, Öztürk F. A pediatric case of cutaneous larva migrans in Turkey. J Pediatr Inf 2020;14(3):e145-e147.

\begin{abstract}
Cutaneous larva migrans is a helminthic infection usually seen in tropical regions. It is transmitted percutaneously and causes serpinginous erythematous eruptions in the skin. Case reports from different regions have also been made due to the widespread cross-country travels. The number of patient notifications in our country is limited. In this article, we aimed to describe the case of a child with no overseas travel history who had atypical localized lesions and gave no response to oral albendazole treatment and thus treated using oral ivermectin.
\end{abstract}

Keywords: Helminthic infection, cutaneous larva migrans, ivermectin

\section{Introduction}

Cutaneous larva migrans (CLM) is known as a parasitosis commonly encountered by people who travel to tropical and subtropical regions and have a history of soil contact (Figures $1,2)$. Once the hookworm penetrates into the body by piercing the skin, they move on by forming tunnels in the epidermis and producing itchy, erythematous, serpiginous lesions. It generally develops due to Ancylostoma braziliensis and Ancylostoma caninum species. Some other lesions associated with secondary bacterial infections may be encountered especially on the foot and buttocks (1). In this report, the case of a child with atypical localization that have not been reported before in Turkey was presented.
Öz

Kütanöz larva migrans genellikle tropikal bölgelerde görülen helmintik bir enfeksiyondur. Perkütan yolla bulaşır ve deride serpingiyöz eritematöz erüpsiyonlara neden olur. Ülkeler arası seyahatlerin yaygınlaşması nedeniyle farklı bölgelerden de vaka bildirimleri yapılmıştır. Ülkemizden az sayıda hasta bildirimi yapılmıştır. Bu yazıda yurt dışı seyahat öyküsü olmayan, albendazol tedavisine cevap alınmayıp tedavide oral ivermektin kullanılan atipik yerleşimli lezyonları olan çocuk olgu sunulmuştur.

Anahtar Kelimeler: Helmintik enfeksiyon, larva migrans, ivermektin

\section{Case Report}

A 2-year-and-7-month-old male patient with complaints of redness and itching on his body for approximately two weeks applied to our hospital. The patient was living in the village of Samsun. It was learned that there was a lot of dog and cat feces in the sand and soil played by the patient who had no history of travel. Skin examination showed an erythematous, slightly raised, serpiginous lesion on the dorsum (Figures 1,2). Lesions on the skin of the patient were considered as cutaneous larval migrans. Laboratory investigations revealed the following; WBC: $8860 / \mathrm{mm}^{3}$, lymphocyte: $3300 / \mathrm{mm}^{3}$, neutrophil: 4300/mm $\mathrm{mm}^{3}$, eosinophil: $320 / \mathrm{mm}^{3}$, hemoglobin: $11.9 \mathrm{~g} / \mathrm{dL}$, platelet: 3424,000 and C-reactive protein: $33 \mathrm{mg} / \mathrm{dL}$, aspartate

\footnotetext{
Correspondence Address / Yazışma Adresi

Şefika İlknur Kökçü Karadağ

Ondokuz Mayıs Üniversitesi Tıp Fakültesi,

Çocuk Sağlığı ve Hastalıkları Anabilim Dalı,

Samsun-Türkiye

E-mail: drilknurkokcu@gmail.com
} 


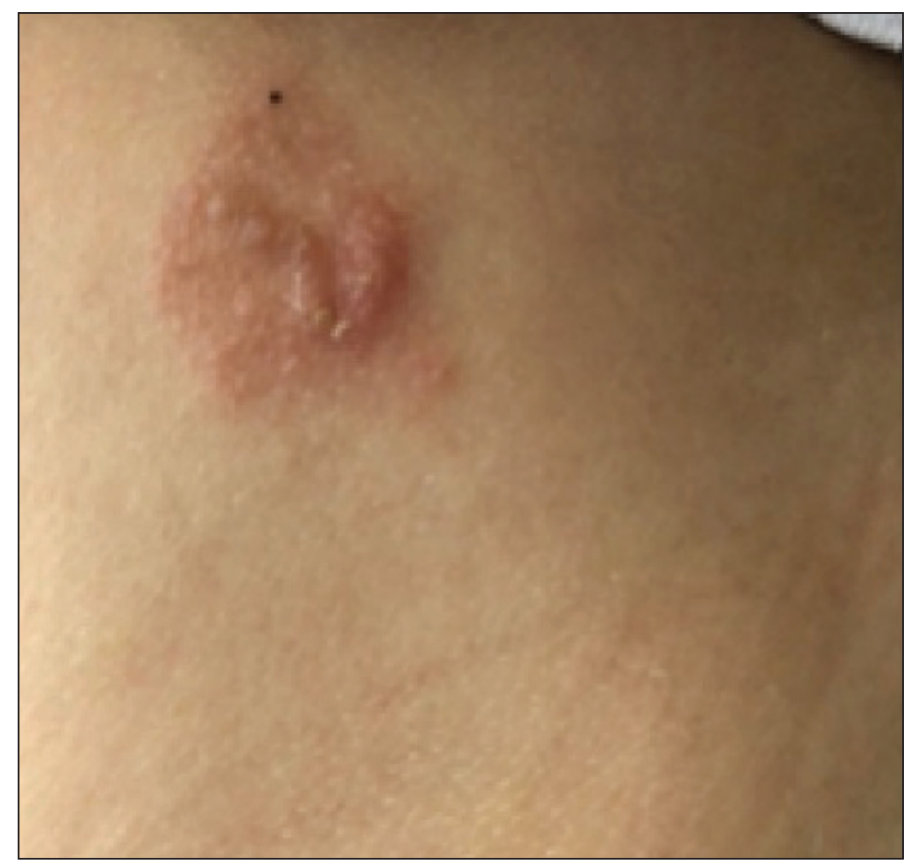

Figure 1. Cutaneous larva migrans lesion in the back.

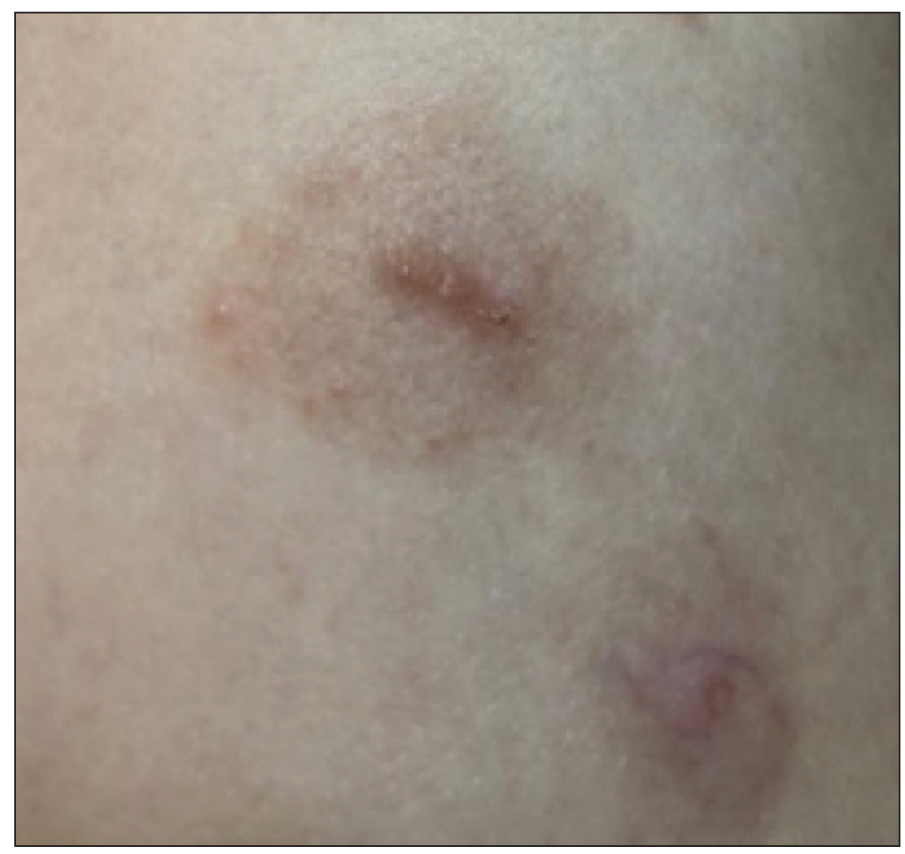

Figure 2. Cutaneous larva lesion on the trunk.

aminotransferase: $29 \mathrm{lU} / \mathrm{mL}$, alanine aminotransferase: $47 \mathrm{IU} /$ $\mathrm{mL}$.

Peripheral eosinophilia was not observed in the patient's laboratory tests. According to chest X-ray, abdominal ultrasonography, and orbital magnetic resonance image results, no feature was detected in terms of visceral involvement. Eye examination was normal. The patient, who was clinically diagnosed as CLM, was treated with oral albendazole for five days. However, because the lesions did not completely regress, the patient was treated with oral ivermectin. Lesions regressed after the treatment of ivermectin.

\section{Discussion}

CLM is most commonly caused by $A$. braziliensis and $A$. caninum species. Diagnosis is based upon the history of contact with dog or cat feces and the presence of tunnels. The disease is clinically characterized by itchy, erythematous, slightly swollen skin, serpiginous, curved or linear lesions between 1-4 $\mathrm{cm}$. The lesions are often seen on foot or buttocks (2). In addition to the general location, CLM has also been reported in the genital area, scalp and body. Systemic complications are rare. Systemic findings include peripheral eosinophilia (Loeffler syndrome), pulmonary involvement, and elevated immunoglobulin E ( $\mathrm{lgE}$ ) levels (3). In our case, the patient did not have eosinophilia or pulmonary involvement. A biopsy can be performed to confirm the diagnosis, but usually no parasites can be seen on histopathological examination. However, since the actual diagnosis was made with clinical history and typical lesion, biopsy was not performed in our patient Oral albendazole and topical ivermectin are used in the treatment. It is known that living in a humid and hot climate and being in contact with soil or sand are important risk factors for the formation of cutaneous larval migraine (CLM). It has been reported that one of the most common skin diseases of travelers and migrants is CLM and that $10 \%$ of skin diseases of people returning from travel are composed of CLM (4). It is known to be the most frequently acquired tropical disease originally found in tropical and subtropical geographic regions such as the southwestern US, Africa, Central and South America and Southeast Asia (5). According to international articles, the number of the cases reported in Turkey is quite few. There are cases previously reported from Düzce, Kütahya, and Ankara provinces from our country. However, there has never been a case report from Samsun province (6-8). There is a history of amazon trip to Brazil in cases reported from Kütahya and Ankara $(7,8)$. However, in cases reported from Düzce, there was the story of working in a hazelnut orchard and mowing weeds using a motorized string trimmer (weed whacker). None of them had a history of travel outside the country (6). All cases reported from Turkey were adults. Cutaneous larval migrans are not seen as endemic in our country. This case was reported because it was a pediatric patient with atypical lesions without a history of travel.

Informed Consent: Patient consent was obtained.

Peer-review: Externally peer-reviewed.

Author Contributions: Concept - ŞiKK, FÖ; Design - ŞiKK, FÖ; Supervision - FÖ, GH; Resources - FÖ, GH; Data Collection and/ or Processing - ŞiKK, GH; Analysis and/or Interpretation - ŞiKK, FÖ; Literature Review - ŞiKK; Writing - ŞiKK; Critical Review - FÖ, GH. 
Conflict of Interest: No conflict of interest was declared by the authors.

Financial Disclosure: The authors declared that this study has received no financial support.

\section{References}

1. Heukelbach J, Feldmeier H. Epidemiological and clinical characteristics of hookworm-related cutaneous larva migrans. Lancet Infect Dis 2008;8:302-9. [CrossRef]

2. Veraldi S, Persico MC, Francia C, Nazzaro G, Gianotti R. Follicular cutaneous larva migrans: a report of three cases and review of the literature. Int J Dermatol 2013;52:327-30. [CrossRef]

3. Schaub NA, Perruchoud AP, Buechner SA. Cutaneous larva migrans associated with Löfler's syndrome. Dermatology 2002;205:207-9. [CrossRef]
4. Sunderkötter $C$, von Stebut E, Schöfer H, Mempel M, Reinel D, Wolf G, et al. S1 guideline diagnosis and therapy of cutaneous larva migrans (creeping disease). J Dtsch Dermatol Ges 2014;12:86-91. [CrossRef]

5. Patel S, Sethi A. Imported tropical diseases. Dermatol Ther 2009;22:53849. [CrossRef]

6. Calıskan E, Uslu E, Turan H, Baskan E, Kilic N. Cutaneous larva migrans: report of three cases from the western black sea region, Turkey. Mikrobiyol Bul 2016;50:165-9. [CrossRef]

7. Aktas H, Gulec Al, Ergin C, Sürücü F. Zosteriform cutaneous larva migrans in a nontropical geography: successful treatment with oral albendazole. J Turk Acad Dermatol 2016;10:16101c7. [CrossRef]

8. Sönmezer MÇ, Erdinç Ş, Tülek N, Babür C, Büyükdemirci A, Ilgar T, et al. Türkiye'de kütanöz larva migrans: bir importe olgu sunumu. Mikrobiyol Bul 2017;51:94-9. [CrossRef] 